Kumawula, Vol. 2, No.3, Desember 2019, Hal 192 - 200 DOI:http://10.24198/kumawula.v1i3.24514 ISSN 2620-844X (online)

Tersedia online di http://jurnal.unpad.ac.id/kumawula/index

\title{
PELATIHAN REPARASI PERALATAN ELEKTRONIK RUMAH TANGGA (LAMPU PENERANGAN LED)
}

\author{
Hikmatul Amri ${ }^{1 *}$, Stephan ${ }^{2}$ \\ ${ }^{1}$ Program Studi Teknik Elektronika, Jurusan Teknik Elektro, Politeknik Negeri Bengkalis \\ ${ }^{2}$ Program Studi Teknik Listrik, Jurusan Teknik Elektro, Politeknik Negeri Bengkalis \\ *Hikmatul_amri@polbeng.ac.id
}

\begin{abstract}
ABSTRAK
Salah satu peralatan elektronika yang paling banyak digunakan oleh masyarakat adalah lampu penerangan. Lampu penerangan rumah dan bangunan mengalami perkembangan yang cukup mulai dari lampu bohlam atau pijar, lampu fluorescent/TL, lampu halogen, lampu LED. Lampu LED sampai saat ini telah mengalami perkembangan LED dual inline package (DIP), LED surface mount device (SMD), HPL (high power LED), dan COB (chip on board). Rangkaian elektronika pada lampu jenis LED hanya terdiri dari 2 bagian yaitu: rangkaian driver dan rangkaian LED yang disusun secara seri. Kerusakan lampu LED paling banyak terjadi pada rangkaian driver dimana ada kerusakan paling ringan yaitu ada komponen yang terbakar sampai kerusakan terparah yaitu seluruh rangkaian yang terbakar. Metoda yang dilaksanakan adalah dengan memberikan pelatihan perbaikan/reparasi lampu jenis LED bagi usaha perbaikan/service peralatan elektronika yang dikelola oleh pemuda RT.05/RW.03 Desa Buruk Bakul. Tahapan yang dilaksanakan adalah memberikan materi komponen yang ada pada lampu LED, memberikan materi tentang komponen yang paling sering terjadi kerusakan pada lampu LED, memberikan praktik cara penggunaan alat ukur analog dan digital, memberikan praktik cara mengecek bagian yang rusak, praktik cara mengganti komponen yang rusak dan tahap melakukan finishing dengan menguji coba terhadap lampu LED yang sudah diperbaiki. Target service ini adalah lampu LED yang ada di sekitar Desa Buruk Bakul dan desa lain yang ingin memperbaiki lampu LED terutama dengan daya yang besar (15-45 watt) karena harga belinya cukup mahal. Dengan mengimplementasikan usaha ini langsung kepada masyarakat maka akan membutuhkan 7-7 orang tenaga kerja, sehingga mampu menambah penghasilan khususnya pada masyarakat kelas bawah di RT.05/RW. 03 Desa Buruk Bakul.
\end{abstract}

Kata Kunci: lampu LED, elektronika, pelatihan, reparasi.

\section{HOUSEHOLD ELECTRONICS (LED LIGHTING) REPAIRS TRAINING}

\begin{abstract}
One of the main electronics used by the public are light bulbs used for lighting. Household and building lighting has undergone an evolution through the times, starting from light bulbs, fluorescent lamps, halogen lamps, and finally LED lights. The development of LED lights created LED with dual inline package (DIP), LED surface mount device (SMD), HPL (high power LED), and COB (chip on board). The electronical network of LED lights consists of 2 parts, namely the driver network and the LED network that are arranged in a series. LED lights usually breakdown due to damage in the driver network. The lightest damage usually involves fire damage to its components and the heaviest damage usually involves fire damage to the whole network. The methods used involve giving LED lights reparations training to electronics repair stores that are run by youths in RT.05/RW.03 Buruk Bakul Village. The training consists of giving materials regarding components in an LED light, the most
\end{abstract}


vurnurable components in an LED light, practice in the use of analog and digital gauges, practice in the process of checking for damages, practice in substituting damaged parts, and the finishing step of testing the repaired LED unit. The main target of these repairs are the LEDs that are in Buruk Bakul Village and other surounding villages that need LED repairs, especially LEDs with large wattage (1545 watt) due to their fairly high prices. With the direct implementation of our program, we need 7 workers, in order to increase the income, especially for the lower class of RT.05/RW.03 Buruk Bakul Village.

Keywords: LED lights, elecronics, training, repairs.

\section{PENDAHULUAN}

Bengkalis merupakan daerah dataran rendah dengan ketinggian rata-rata sekitar 2 sampai 6,1 m dari permukaan laut. Pada tahun 2013 kabupaten bengkalis termasuk daerah 3T (tertinggal, terdepan dan terluar) di Indonesia sehingga akses untuk mendapatkan sentuhan teknologi terbilang agak terlambat, akan tetapi pada tahun 2017 wilayah kabupaten Bengkalis sudah beralih status menjadi daerah $2 \mathrm{~T}$ (terdepan dan terluar). Salah satu desa yang ada di Kabupaten Bengkalis adalah Desa Buruk Bakul.

Desa Buruk Bakul merupakan salah satu desa yang termasuk dalam wilayah Kecamatan Bukit Batu. Berdasarkan data dari Badan Pusat Statiktik, luas wilayah desa Buruk Bakul adalah 78 KM2 dengan jumlah penduduk sebanyak 1159 orang yang terdiri dari 617 laki-laki dan 547 perempan. Sebaran penduduk menurut pendidikan adalah tamat SD 320 orang, tamat SMA 495 orang, tamat sarjana 106 orang dan belum sekolah 238 orang. Sebaran penduduk menurut mata pencairan atau pekerjaan, yang terbesar adalah pelajar 423 orang, ibu rumah tangga 329 orang, dan belum bekerja tetap 407 orang (BPS, 2015). Penghasilan masyarakat sebagian besar dari hasil kebun karet dan nelayan.

Selama ini masyarakat Desa Buruk Bakul dalam memenuhi kebutuhan kehidupan sehari-hari berasal dari karet dan nelayan, sebagian kecil lainnya adalah buruh kebun sawit dan berdagang. Seperti yang diketahui bersama harga karet beberapa tahun terakhir tidak stabil (naik dan turun), antara 5000-8000 rupiah/kilo. Harga terbaru karet saat ini berada pada kisaran 6000an rupiah/kilo membuat kehidupan ekonomi masyarat desa Buruk Bakul semakin terpuruk. Begitu juga yang berprofesi sebagai nelayan, tidak bisa terus menerus melaut karena perubahan cuaca yang ekstrim (angin dan gelombang yang tidak menentu). Sehingga kehidupan ekonomi sebagian besar masyarakat di bawah standar layak (Amri dan Syaiful, 2017).

Kelompok usaha di desa buruk bakul bisa dibilang tidak ada sama sekali. Meskipun ada bantuan usaha biasanya diberikan dalam bentuk uang kepada perorangan bukan perkelompok usaha, sehingga tidak maksimal dalam penyerapan tenaga kerja. Oleh karena itu, perlu 
dilakukan pengembangan usaha kecil home industri yang mampu menambah penghasilan bagi masyarakat kelas menengah dan ke bawah (Saifuddin, 2013).

Dalam hal ini, kegiatan pelatihan bertujuan untuk memberikan pelatihan reparasi peralatan elektronika difokuskan perbaikan lampu penerangan jenis LED karena lampu jenis ini paling banyak digunakan saat ini karena dayanya yang kecil tetapi cahaya yang dihasilkan sangat terang. Tujuan akhir dari kegiatan pengabdian ini adalah memberikan tambahan pendapatan bagi masyarakat yang menjadi pekerja pada usaha service elektronika.

\section{METODE}

Bagan alir pencapaian tujuan dalam kegiatan pengabdian dana PNBP Polbeng tahun 2019 dapat dilihat pada Gambar 1.

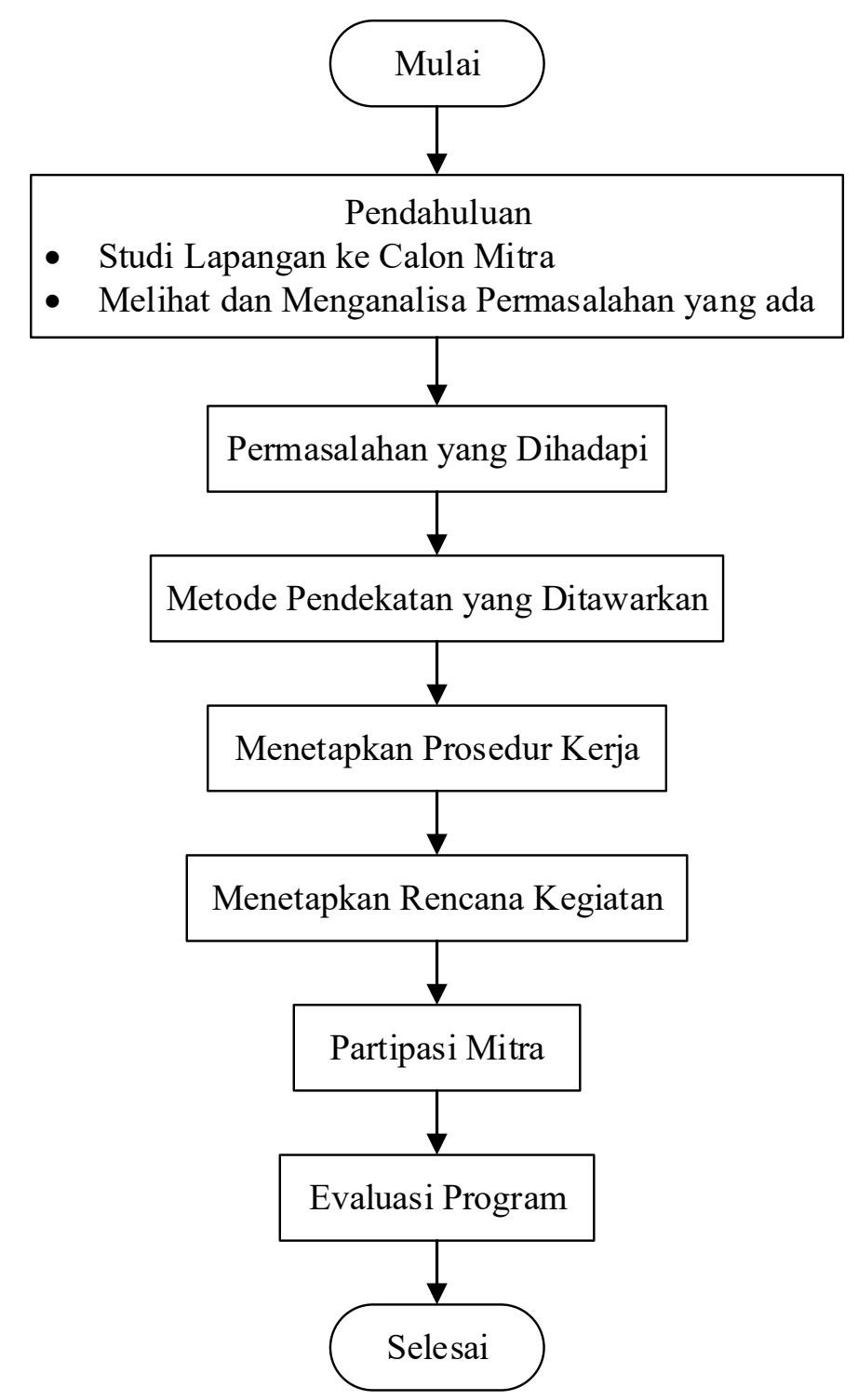

Gambar 1. Alur Kerja Program Yang Diusulkan 
Studi lapangan dan diskusi dilakukan untuk mendapat informasi jumlah penduduk, informasi masyarakat sumber mata pecarian utama penduduk di desa Buruk Bakul. Studi dilakukan dengan dengan melihat langsung sumber mata pencarian di desa Buruk Bakul. Setelah melaksanakan studi lapangan pengusul menetap 2 (satu) mitra yaitu mitra 1 adalah kelompok usaha yang sudah dibentuk yaitu: kelompok usaha Kit Elektronik Service, dan mitra kedua adalah ketua RW.03 sebagai yang menjadi naungan bagi kelompok usaha.

Berdasarkan hasil wawancara dengan diperoleh informasi sebagian besar masyarakat desa Buruk Bakul memiliki mata pencarian buruh tani karet dan nelayan. Dan dari data lapangan didapatkan harga karet saat ini sangat rendah (6000 rupiah/kilo), sehingga perlu adanya tambahan penghasilan agar kondisi ekonomi mereka dapat terbantu dengan adanya kelompok usaha ini. Sehingga dengan adanya kegiatan pelatihan ini dapat menambah pengaembangan usaha yang sudah ada pada Kit Elektronik Service.

Berdasarkan pantauan dan analisis yang sudah dilakukan, dapat dibuat kesimpulan permasalahan yang dihadapi sebagian besar masyarakat desa Buruk Bakul adalah kurangnya modal dalam membuat usaha dan kurangnya pengetahuan mereka dalam memilih usaha yang bisa laku dipasaran. Sehingga dengan pelatihan yang dilakukan dapat menambah pengetahuan dan keterampilan mereka dalam memperbaiki peralatan elektronik khususnya perbaikan lampu penerangan Jenis LED.

Metode yang ditawarkan dalam program Pengabdian PNBP 2019 adalah memberikan pelatihan tata cara memperbaiki perlatan eletronika khusunya perbaikan lampu penerangan jenis LED karena lampu ini sangat banyak dipakai masyarakat pada umumnya. Setiap lampu yang diperbaiki mereka bisa mendapatkan keungtungan mulai dari 5000-20.000 rupiah tergantung kerusakan yang diperbaiki. Waktu pelaksanaan kegiatan pengabdian PNBP ini lebih kurang 4 bulan terhitung sejak proposal diajukan. Peseta akan dibekali dengan materi teoritis terlebih dahulu baru kemudian dilakukan praktik perbaikan/reparasi lampu LED.

Sebelum melaksanakan kegiatan perlu ditetapkan prosedur kerja dengan tujuan setiap kegiatan yang dilaksanakan terarah. Prosedur kerja diawali dengan menetapkan mitra kerja. Dalam hal ini mitra kerja adalah kelompok usaha yang dibentuk dengan anggota 4-8 orang yang merupakan pegawai lepas (freelance). Kemudian dilakukan penerapan dan penggunaan teknologi dengan melatih anggota untuk memperbaiki lampu jenis LED.

Penetapan rencana kegiatan berhubungan dengan lamanya atau waktu yang dibutuhkan dalam menjalankan program sehingga mitra benar-benar telah memahami dan menerapkan 
teknologi yang ditawarkan dalam rangka meningkatkan pengetahuan anggota kelompok usaha untuk menggunakan peralatan yang diberikan. Oleh karena itu, akan dilakukan pelatihanpelatihan khusus, sehingga mereka benar-benar mampu memperbaiki lampu LED yang rusak baik rusak ringan maupun rusak berat.

Peran serta mitra dalam pelaksanaan program sangat diharapkan, anggota kelompok usaha akan diberikan penyuluhan mulai dari materi awal, perkelnalan alat dan bahan sampai dengan perbaikan, selain itu juga mereka akan diberikan pelatihan khusus dalam memelihara dan memperbaiki peralatan yang diberikan/dihibahkan.

Evaluasi program merupakan suatu unit atau kesatuan kegiatan yang bertujuan mengumpulkan informasi tentang realisasi atau implementasi dari suatu kebijakan, berlangsung dalam proses yang berkesinambungan, dan terjadi dalam suatu organisasi yang melibatkan sekelompok orang guna pengambilan keputusan.

\section{HASIL DAN PEMBAHASAN}

\section{Isi Hasil dan Pembahasan}

Kegiatan reparasi peralatan elektronik rumah tangga (lampu penerangan LED) ini telah dilaksanakan dari tangggal 3 sampai dengan 4 Nopember 2019. Pelatihan ini diikuti sebanyak 8 peserta. Pelatihan reparasi peralatan elektronik rumah tangga (lampu penerangan LED) ini terdiri dari dua tahap yaitu tahap penyampaian/pembekalan meteri dan tahap praktek perbaikan. Materi yang disampaikan seperti materi materi penunjang praktik seperti pengenalan komponen dan sistem kerja lampu LED, pengenalan peralatan kerja perbaikan lampu LED, teknik dasar perbaikan lampu LED, prosedur dasar bongkar pasang lampu LED dan prosedur/urutan kerja perbaikan lampu LED.

Gambar 2 memperlihatkan proses pelatihan yang dimulai dari Opening dan Introduction dengan peserta pelatihan mengenai hal-hal yang berkaitan dengan kegiatan pelatihan. Gambar 3 pelaksanaan pembekalan secara teoritis materi mulai dari fungsi peralatan dan bahan/komponen yang dibutuhkan sampai dengan materi bagian bagian utama dari lampu penerangan LED beserta fungsinya. 


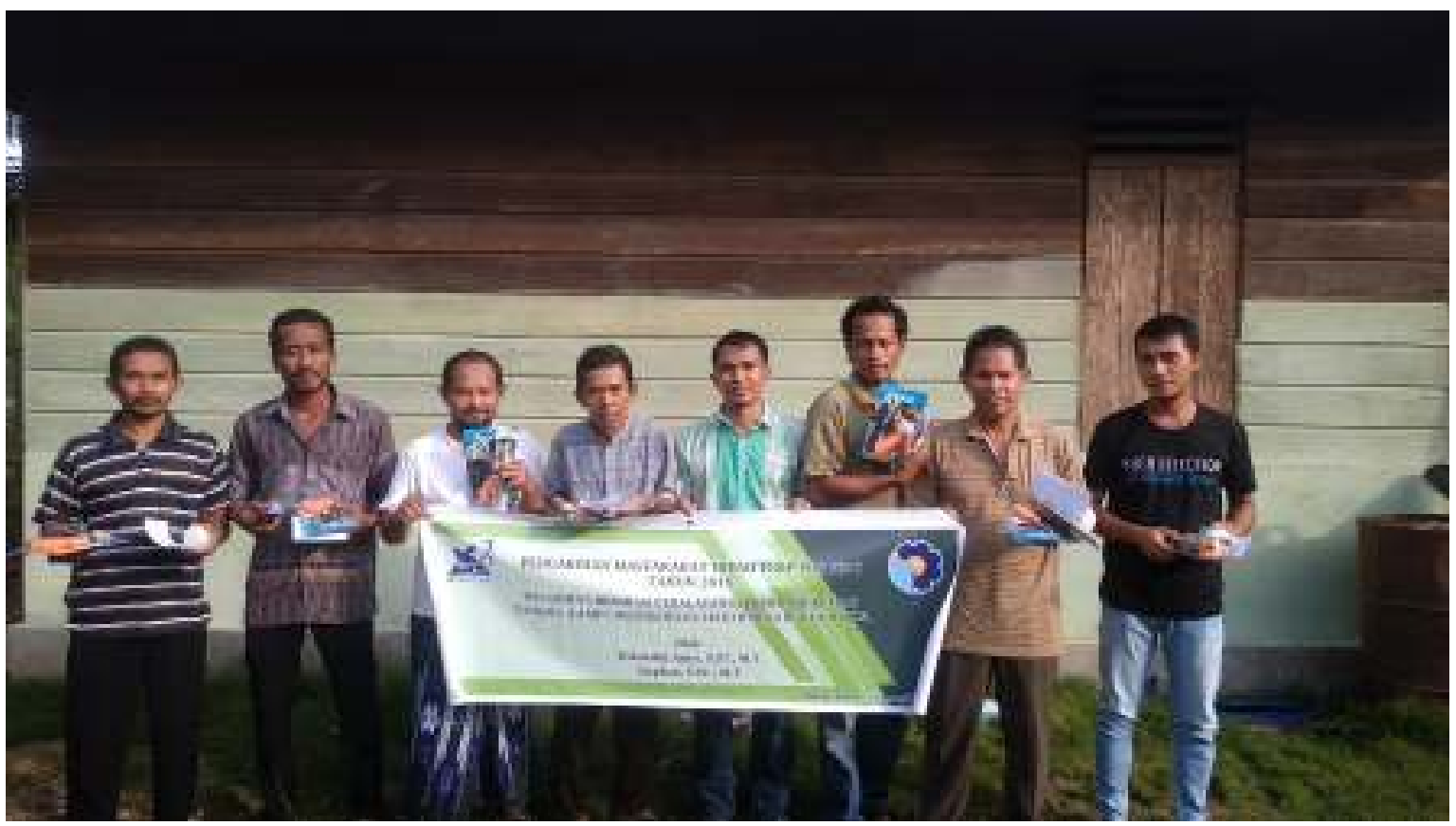

Gambar 2. Acara opening dan introduction

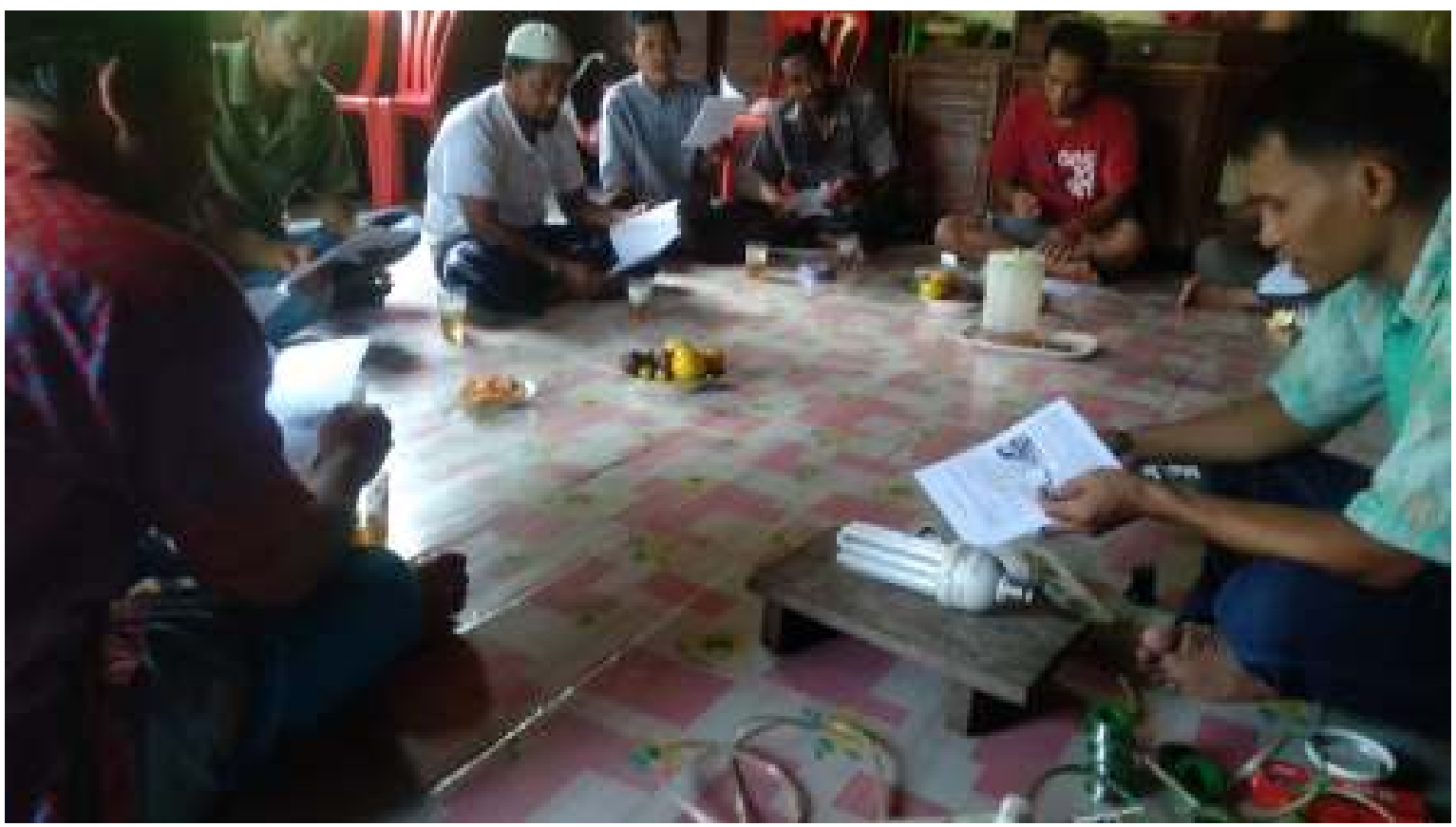

Gambar 3. Penyampai materi

Kegiatan pelatihan mencakup proses pembongkaran cup penutup lampu LED sampai pengecekan LED yang rusak seperti pada Gambar 4 dan cara memperbaikinya seperti pada Gambar 5, serta cara penggantian rangkaian driver yang rusak dengan yang baru seperti Gambar 6. Peserta secara langsung mempraktekkan tata cara tersebut didampingi oleh pemateri. 


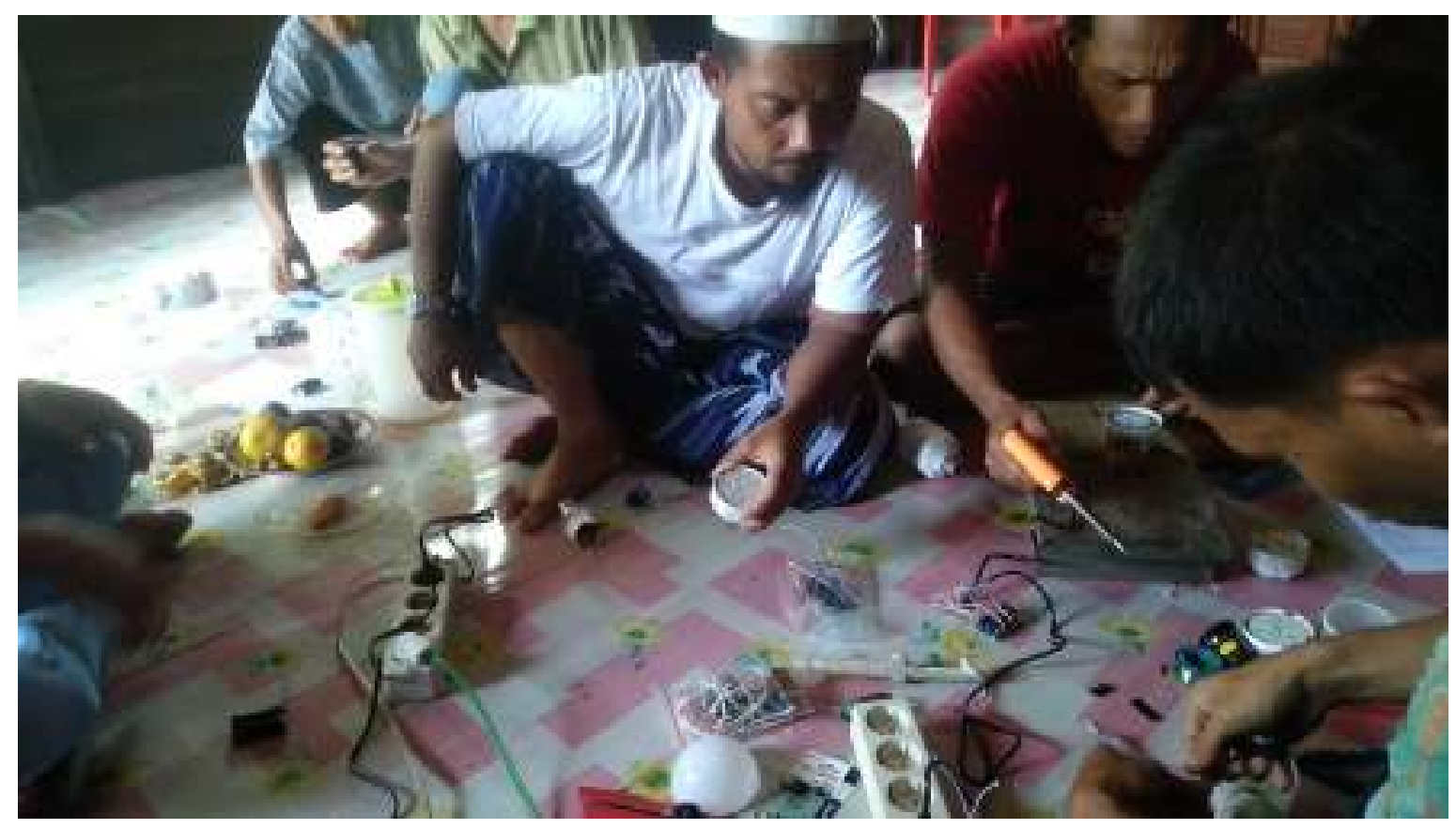

Gambar 4. Proses pengecekan LED

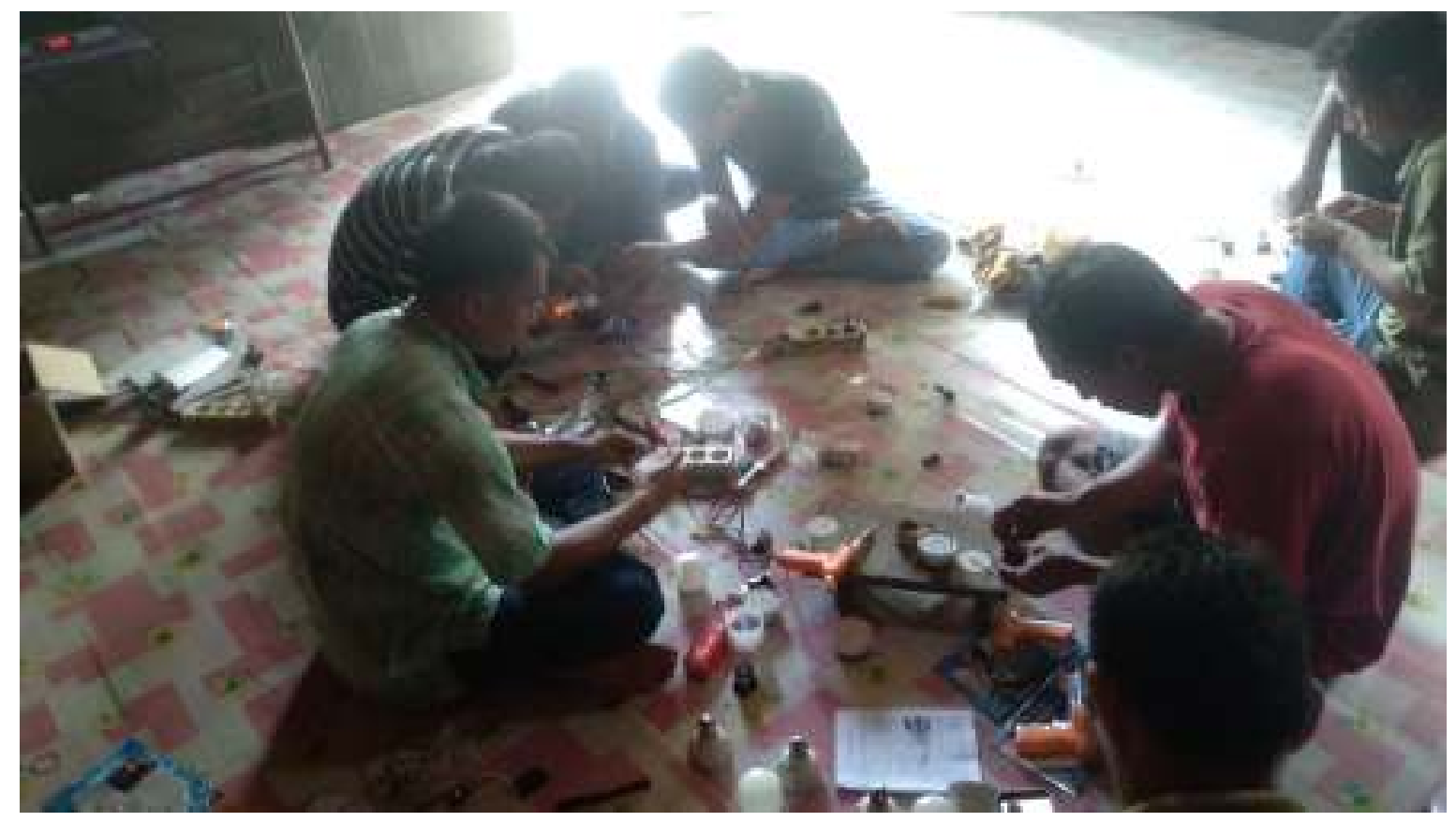

Gambar 5. Proses perbaikan LED yang rusak 


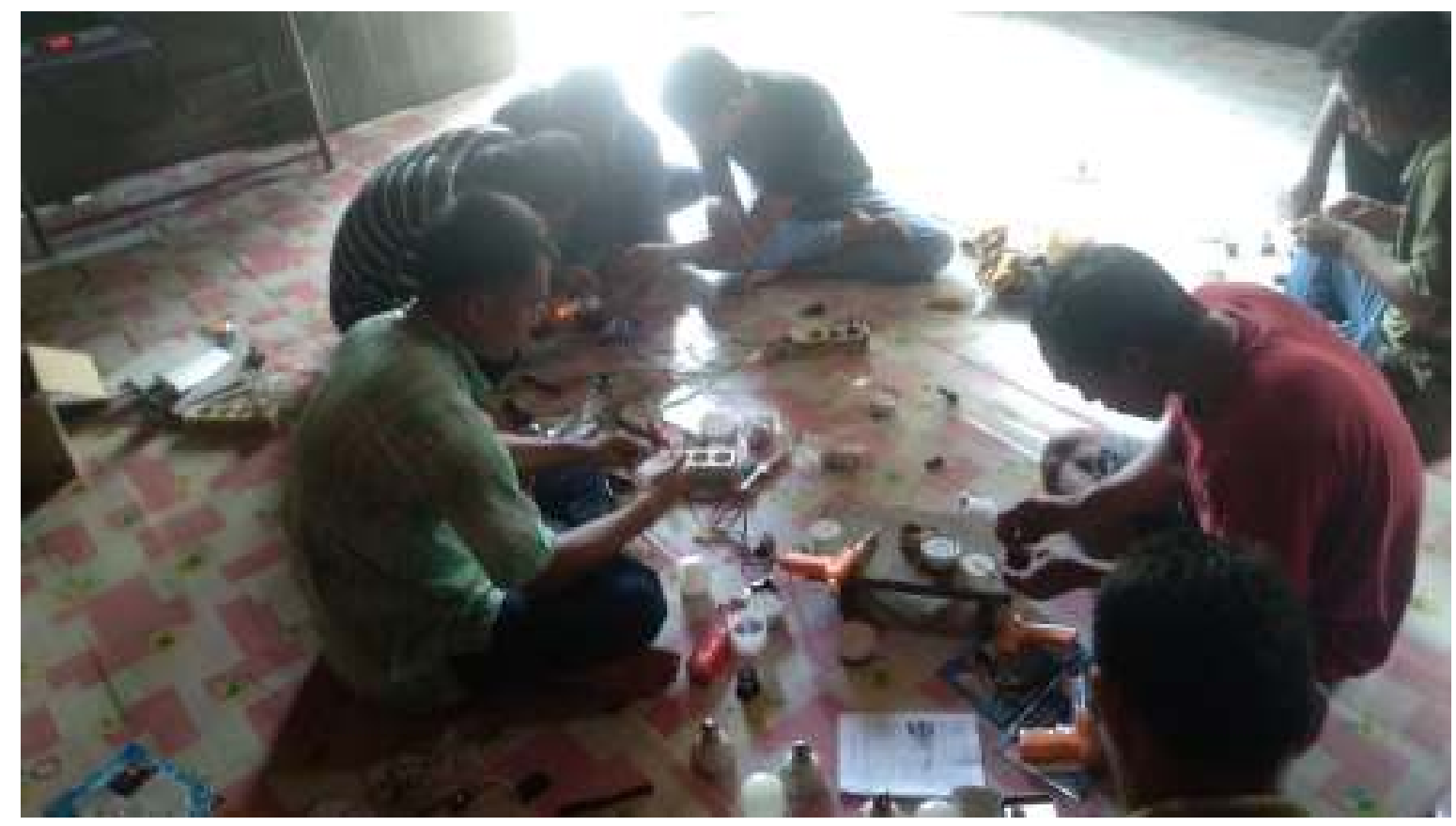

Gambar 6. Proses penggantian driver LED

Setelah dilakukan perbaikan lampu LED harus diuji coba terlebih dahulu sebelum pemasangan kembali penutup cup dan drat E27 (drat fitting). Setelah uji coba berhasil, barulah pekerjaan finishing dilakukan dengan memasang kembali cup penutup LED dan pemasangan drat E27 dan dilakukan kembali pengetesan terakhir lampu LED seperti pada Gambar 7.

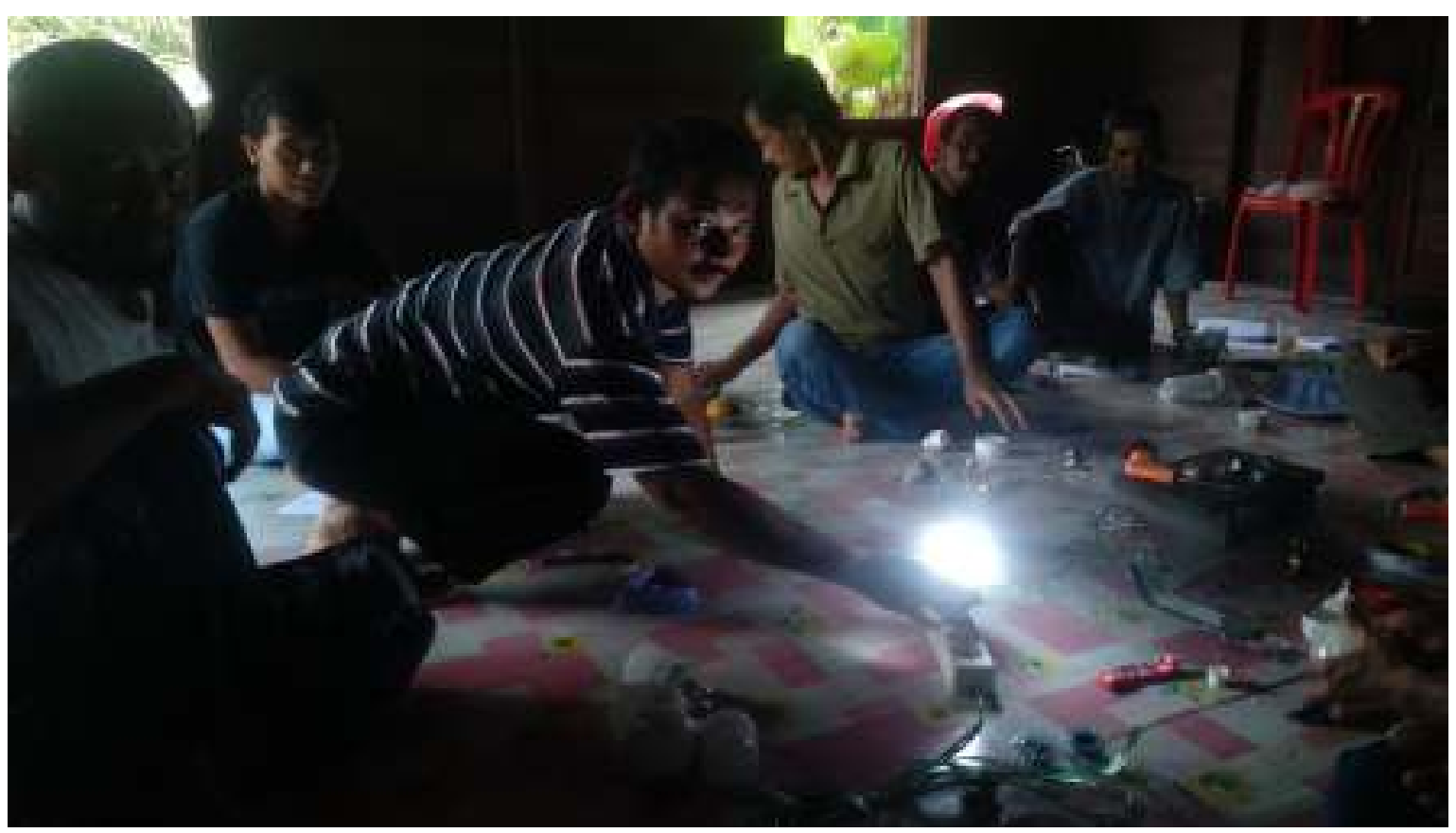

Gambar 7. Proses uji coba akhir Lampu LED setelah perbaikan 


\section{SIMPULAN}

Pelatihan reparasi peralatan elektronik rumah tangga (lampu penerangan LED) dimaksud untuk memberikan memberikan pengetahuan dan keterampilan dalam perbaikan lampu LED kepada kelompok usaha Kit Elektronik Service Desa Buruk Bakul sehingga kelompok usaha memperoleh pengetahuan dalam reparasi peralatan elektronik rumah tangga sehingga mendapatkan bekal yang positif dalam pengembangan usahanya.

Pada kegiatan Pelatihan ini terdapat 10 lampu LED yang rusak dan 8 diantaranya berhasil diperbaiki dengan kerusakan yang beragam, yaitu: 3 lampu mengalami kerusakan LED tanpa kerusakan rangkaian driver LED dan 5 lampu LED kerusakan rangkaian driver tanpa kerusakan LED.

Untuk kegiatan selanjutnya kelompok mitra berharap ada kegiatan pelatihan serupa untuk perbaikan ataupun perawatan peralatan listrik rumah tangga yang lain seperti: perbaikan seterika, rice cooker, kipas angin dan lain lain.

\section{DAFTAR PUSTAKA}

Badan Pusat Statistik Kabupaten Bengkalis, (2019), Kecamatan Bukit Batu Dalam Angka 2019. CV. M\&N Grafika,

Amri, H. dan Syaiful, A., (2017), Pengolahan Air Tanah Artesis Menjadi Air Layak Minum Di Desa Buruk Bakul. Prosiding Semnas IIB Darmajaya, Bandar Lampung, hal. 75-81.

Saifuddin Z., (2013), Analisis Pengembangan Usaha Kecil Home Industri Sangkar Ayam Dalam Rangka Pengentasan Kemiskinan, Jurnal Manajemen dan Akuntansi. Volume 2, No. 3, hal. 46-65. 